\title{
Endogenous tumor necrosis factor $\alpha$ mediates enhanced apoptosis of cultured villous trophoblasts from intrauterine growth-restricted placentae
}

\author{
R T Kilani ${ }^{1,2}$, M Mackova ${ }^{1,2}$, S T Davidge ${ }^{1,3}$, B Winkler-Lowen $^{1,2}$, N Demianczuk $^{3}$ \\ and L J Guilbert ${ }^{1,2}$ \\ ${ }^{1}$ University of Alberta Perinatal Research Centre, Edmonton, Canada, Departments of ${ }^{2}$ Medical Microbiology and \\ Immunology and ${ }^{3}$ Obstetrics and Gynaecology, University of Alberta, Edmonton, Canada
}

Correspondence should be addressed to L J Guilbert, 6-25 HMRC, 8440-112 Street, University of Alberta, Edmonton, Canada T6G 2S2; Email: larry.guilbert@ualberta.ca

\begin{abstract}
Tumor necrosis factor $\alpha$ (TNF $\alpha$ ) has been implicated in the abnormally high levels of trophoblast apoptosis seen in placentae from pregnancies complicated by small births. We examined the hypothesis that at physiological (35-50 mmHg) oxygen tensions, the production of TNF $\alpha$ stimulates the apoptosis of placental trophoblasts associated with infants that are intrauterine growth-restricted (IUGR). Highly purified cytotrophoblasts (CT) from IUGR-complicated pregnancies spontaneously underwent a higher rate of apoptosis after $24 \mathrm{~h}$ of culture at a normoxic (for villous CT) tension of $38 \mathrm{mmHg}$ than did CT from normal placentae. Real-time PCR

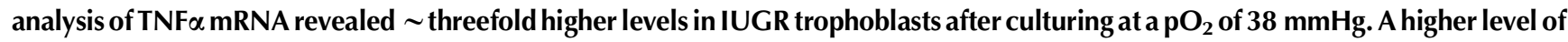
TNF $\alpha$ receptor p55 (which mediates apoptosis) was found in IUGR CT by western blot analysis at pO $\mathrm{pof}_{2}<10,38$, and $140 \mathrm{mmHg}$. Neutralizing antibody to TNF $\alpha$ significantly inhibited the apoptosis of IUGR trophoblasts cultured at $38 \mathrm{mmHg}$ and addition of TNF $\alpha$ significantly elevated apoptosis of normal and IUGR trophoblasts but less in IUGR cells cultured at $<10 \mathrm{mmHg}$. We conclude that at physiological oxygen tensions $(38 \mathrm{mmHg})$, villous CT from IUGR pregnancies, when compared with uncomplicated pregnancies, undergo more TNF $\alpha$-induced apoptosis both because of elevated expression of TNF $\alpha$ and TNF receptor p55.

Reproduction (2007) 133 257-264
\end{abstract}

\section{Introduction}

Early pregnancy loss leading to fetal death, preterm birth of a live fetus, and birth of a small fetus (IUGR; Mintz et al. 1986, Rubbert et al. 1992, Ticconi et al. 2003, Wong et al. 2004) together constitute a significant proportion of pregnancy complications, and cause significant maternal and fetal morbidity and mortality. Alterations in placental oxygen levels are implicated in the pathophysiology of all the three disorders (Salafia et al. 1995, Pardi et al. 2002, Jauniaux et al. 2006). Indeed, chronic hypoxia is one of the most common insults to the conceptus and is associated with IUGR (Kingdom et al. 2000). Prior to $\sim 10$ weeks of gestation, the human placenta develops in a low oxygen environment but subsequent remodeling of maternal spiral arteries allows a direct flow of maternal blood from peripheral circulation (reviewed in Benirschke \& Kaufmann 2000). As pregnancy advances, blood normally enters the placenta via a maternal arteriole at an oxygen tension of about $100 \mathrm{mmHg}$ and leaves the intervillous space in a maternal venule at about $40 \mathrm{mmHg}$ (Soothill et al. 1986, Sibley et al. 2002). Oxygen extracted by the placenta is delivered into the fetal umbilical vein at about $27 \mathrm{mmHg}$ where it supplies the oxygen demands of the fetus.

The site of gas exchange to the fetus is the villous placenta which consists of an outer layer of syncytiotrophoblast (ST), a continuous, mature and non-proliferating cell that faces the intervillous space (maternal blood) with a microvillous surface (reviewed in Benirschke \& Kaufmann 2000). Directly beneath the ST are cytotrophoblasts (CT) which are cells with a single nucleus, cluster near fetal blood vessels in the third trimester and replicate and fuse with the ST to repair or expand it. The trophoblast basal lamina lies beneath the trophoblast layer and separates the trophoblast from the fetal stroma consisting of fibroblastic cells, fetal macrophages, and fetal vascular endothelium. The distance between the intervillous space and the villous blood vessels involved in gas exchange is small $(<20 \mu \mathrm{m})$. 
Therefore, it is difficult to assign an oxygen tension in the immediate vicinity of $\mathrm{CT}$, but it would be predicted to average about 30-45 $\mathrm{mmHg}$ for both normal and IUGR placentae (Hung et al. 2001).

IUGR placental villi are smaller in all cellular aspects (Mayhew et al. 2003), but the trophoblasts undergo an elevated frequency of apoptosis when compared with their normal counterparts (Smith et al. 1997). We have found that CT cultured with TNF $\alpha$ enhanced apoptosis (Yui et al. 1994a), which was stimulated via the TNF p55 receptor (Yui et al. 1996). Previous studies have shown that the CT isolated from IUGR pregnancies undergo elevated apoptosis rates, compared with normal CT, when cultured at the hypoxic oxygen tension of $23 \mathrm{mmHg}$ (Crocker et al. 2003). These authors also implicated elevated TNF $\alpha$ as a mediator but its role was not established. However, in a study with CT isolated from normal placentae, we found that these cells were remarkably resistant to chronic hypoxia, with the lowest rate of apoptosis observed at 15 and $38 \mathrm{mmHg}$, and that apoptosis increased only when the cells were cultured in $<10 \mathrm{mmHg}$ (Kilani et al. 2003).

Since the oxygen levels that IUGR CT are exposed to in vivo likely are not greatly different from those of normal villous $\mathrm{CT}$, we hypothesized that any abnormal apoptosis in IUGR should manifest at the relatively normoxic range of $38 \mathrm{mmHg}$. We tested this hypothesis by culturing cells at three different oxygen levels (140, 38 , and $<10 \mathrm{mmHg}$ ) measuring the frequency of apoptosis, the levels of TNF $\alpha$ mRNA, and the levels of TNF receptor p55 by western blot analysis.

\section{Materials and Methods \\ Isolation, purification, and culture of term villous cytotrophoblasts}

Placentae were obtained after normal term deliveries or term elective cesarean sections from either uncomplicated or IUGR-complicated pregnancies (we find no differences in apoptosis between vaginal- and caesarean-delivered placentae). An IUGR pregnancy was defined as a term delivery of an infant at $\leq 10$ th weight centile of all deliveries in Edmonton (the inclusion criterion). Other than fetal weight $\geq 90$ th centile, there were no other exclusion criteria. Mothers were not segregated by smoking, pre-eclampsia or other pregnancy complication other than weight of their baby. Four out of the nine mothers with an IUGR pregnancy also had pre-eclampsia and one of these (the only one of the nine) had absent end diastolic flow in the uterine artery. Gestational ages of normal and IUGR placentae were not statistically different (normal: $n=9$, average $=38.4 \pm$ 0.6 weeks; IUGR: $n=9$, average $=36.2 \pm 3.8$ weeks; $P<0.13$ ). Villous mononuclear trophoblasts were isolated by trypsin/DNase digestion of minced chorionic tissue and immunoabsorption on to Ig-coated glass bead columns as previously described (Yui et al. 1994b, Kilani et al. 1997, Guilbert et al. 2002) using anti-major histocompatibility complex (MHC) class I (W6/32, Harlan Sera-Lab, Crawley Down, Sussex, England), anti-CD9 (clone50H.19), and anti-MHC class II (clone 7H3) antibodies for immunoelimination (the latter two were prepared in our laboratory). The yield of the resulting population is approximately $67 \%(n=8)$ of starting unpurified cells with a range of $2-8 \times 10^{8} \mathrm{CT}$ per placenta. After adhesion to tissue culture dishes and washing as described below, the resulting cultures contain fewer than five vimentin-positive (non-trophoblasts) cells $/ 10^{5}$ plated and are almost completely free of mononuclear syncytial fragments (Guilbert et al. 2002). The cells were cryopreserved and thawed as described previously (Yui et al. 1994b, Guilbert et al. 2002). The thawed cells were cultured in Iscove's Modified Dulbecco's Medium (IMDM, GIBCO) supplemented with $10 \%$ fetal bovine serum (FBS, GIBCO) and antibiotics (end concentrations: penicillin $100 \mathrm{U} / \mathrm{ml}$, streptomycin $100 \mu \mathrm{g} / \mathrm{ml}$; Sigma) at seeding densities between 5.0 and $7.5 \times 10^{5}$ cells $/ \mathrm{ml}$ in 24-well plates (Corning, NY, USA). The cells were allowed to attach for $5 \mathrm{~h}$, washed with warm IMDM and pre-equilibrated (at the appropriate oxygen level) 2\% FBS-IMDM or medium containing TNF- $\alpha(10 \mathrm{ng} / \mathrm{ml}$; a gift of Hoffmann LaRoche, Basel, Switzerland) or antibody to TNF- $\alpha$ (at final concentration of $2 \mu \mathrm{g} / \mathrm{ml}$, a dose that neutralizes $1 \mathrm{ng} / \mathrm{ml}$ TNF $\alpha$ (data not shown), Upstate Biotechnologies, Lake Placid, NY, USA) added. The cells were then incubated for $24 \mathrm{~h}$ in one of the following culture environments (all of which are fully humidified): (i) in a standard $5 \% \mathrm{CO}_{2}$ in air incubator $\left(\mathrm{pO}_{2}\right.$ $140 \mathrm{mmHg}$ ); (ii) in a controlled oxygen incubator (Forma Series II, Forma, Marietta, OH, USA) regulated at $5 \% \mathrm{CO}_{2}$ and $5 \%$ oxygen $\left(\mathrm{pO}_{2} 38 \mathrm{mmHg}\right)$ with the balance being nitrogen; and (iii) in a modular-incubator chamber (Billups-Rothenberg, DeMar, CA, USA) in which air was replaced with nitrogen containing $5 \%$ $\mathrm{CO}_{2}$ by a time and flow $(15.0 \mathrm{~min}, 200 \mathrm{ml} / \mathrm{s})$ controlled purge $\left(\mathrm{pO}_{2}<10 \mathrm{mmHg}\right)$. The oxygen tension of the media in the different culture environments was measured as described previously (Kilani et al. 2003). All experiments were carried out independently at least twice.

\section{Measurements of apoptosis}

A total of nine different IUGR placental preparations were used in the study and compared with nine representative normal placentae. Nuclear DNA fragmentation in apoptotic cells was detected using terminal deoxynucleotidyl transferase (TdT)-mediated dUTP-biotin DNA-nick end labeling (TUNEL; Gavrieli et al. 1992) in trophoblast cultures as described previously (Yui et al. 1994a). The number of apoptotic and non-apoptotic nuclei was assessed by counting and averaging ten randomly selected $0.25 \mathrm{~mm}^{2}$ microscopic fields in each 
of the three replicate wells (magnification, $\times 200$ ) with a Zeiss Telaval 31 inverted microscope (Carl Zeiss, Thornwood, NY, USA). Apoptosis was also assessed by the fraction of DAPI (4,6-diamidino-2-phenylindole) bright nuclei. DAPI $(150 \mu \mathrm{g} / \mathrm{ml})$ was added to trophoblasts, fixed with $1 \%$ paraformaldehyde $(10 \mathrm{~min}$ at room temperature), and then removed with two gentle washes with PBS. The cells were then visualized with an inverted phase contrast microscope (Model DS-IRB, Leica; Heerbrugg, Switzerland) equipped for epifluorescence with a $100 \mathrm{~W}$ high-pressure mercury lamp driven by a Ludl power source (Ludl Electronic Products; Hawthorne, NY, USA). Digital images of ten fields of each well of 24-well plates were taken with a blue filter using a SPOT digital camera (Diagnostic Instruments; St Sterling Height, Michigan, IL, USA) and the images manually evaluated for the percentage DAPI bright. The fraction of TUNEL-positive nuclei in trophoblast cultures parallels the appearance of characteristic uniform DNA degradation patterns (ladders; Yui et al. 1994a, Garcia-Lloret et al. 1996) and is identical to the fraction of compacted nuclei detected by differential propidium iodide (Yui et al. 1996) and DAPI (present paper) staining. Therefore, apoptosis was assessed by either TUNEL or DAPI.

\section{Measurement of TNF $\alpha$ by bioassay and by quantitative (q) RT-PCR}

Supernatants were saved and frozen at $-20^{\circ} \mathrm{C}$ until analysis. Thawed supernatants were assayed for TNF- $\alpha$ bioactivity using recombinant human TNF- $\alpha$ standards in the L929-8 bioassay as described previously (Branch et al. 1991). The lowest level of detection was $1 \mathrm{pg} / \mathrm{ml}$.

We carried out the TNF $\alpha$ mRNA analysis on samples from normal and IUGR cells (three independent experiments each) cultured for 3, 6, and $12 \mathrm{~h}$ (times start after the 5-h adhesion step) at three different oxygen tensions with cells from six different placentae. The results were very similar for each of the time points and only the 3-h data are presented. The primers and probe specific for human TNF $\alpha$ were purchased from Applied Biosystems (Foster City, California, USA). The sequences for primers and probes are confidential information, but the lot (G03991) was tested at the factory for reliability with a Stratagene Reference Set. HPLC-purified human 18S primers (forward: ctaccacatccaaggaaggc and reverse: gactcattccaattacagggc) were synthesized by Operon Biotechnologies (Huntsville, AL, USA). The cells were lysed with Trizol Reagent (GIBCO BRL Life technologies), total RNA was extracted using the protocol supplied by the manufacturer, and RNA integrity was verified by electrophoresis and visualization with ethidium bromide staining and by an average optical density (OD) 260/OD280 absorption ratio of 2.11. Total RNA ( $1 \mu \mathrm{g})$ was reverse transcribed, the reverse transcriptase was inactivated by heating at
$70{ }^{\circ} \mathrm{C}$ for $15 \mathrm{~min}$ and the resulting CDNA was used for qPCR amplification of TNF $\alpha$ as described previously (Arenas et al. 2004). The experiments were performed in triplicate for each sample. The reference gene $18 \mathrm{~S}$ rRNA was run concurrently to normalize the results obtained. The amplification efficiency for each primer set was determined by converting the slope of the standard curve using the algorithm $E=10^{-1 / \text { slope }}$ (Pfaffl 2001). For each gene, the mean threshold cycle, corrected for the efficiency of the reaction, was expressed relative to the control sample and the mean of each treatment group was determined.

\section{Western blot analysis}

Sample protein concentrations were determined in duplicate with Micro BCA Reagent (PIERCE Chemical Company, Rockford, IL, USA) with a serum albumin standard. Sample protein (15-20 $\mu \mathrm{g})$ was solubilized in $3 \times$ sample buffer (Sigma) by boiling for $5 \mathrm{~min}$ and stored at $-20^{\circ} \mathrm{C}$ until electrophoresis. SDS-PAGE was performed according to the procedure of Laemmli (1970) using 10\% acrylamide (Mini-Protein II gel system, BioRad Laboratories, Inc.), blotted onto nitrocellulose membranes, the blots incubated overnight at $4{ }^{\circ} \mathrm{C}$ with a specific antibody (anti-TNF- $\alpha$ receptor p55, rabbit polyclonal, antigen purified and used at $4 \mu \mathrm{g} / \mathrm{ml}$, Stressgen, Victoria, BC, Canada), exposed to X-ray film, band density after exposure digitized, and analyzed as described previously (Mackova et al. 2003).

\section{Statistical analysis}

The number of placentae and replicate experiments is described in individual figure legends. Differences between experimental groups were evaluated by twoway ANOVA with pairwise multiple comparison procedures (Tukey Test) and Student's $t$-test using the SigmaStat program (Jandel Scientific, San Rafael, CA, USA) as explained in the figure legends. Results are expressed as mean \pm s.D. and were considered to be significant at $P<0.05$.

\section{Results}

\section{The frequency of apoptosis in CT isolated from IUGR compared with uncomplicated pregnancies as a func- tion of oxygen tension}

The apoptosis frequency of a preparation was assessed at oxygen tensions of 140,38 and $<10 \mathrm{mmHg}$ at the same time to minimize errors. Representative assessments of apoptosis for trophoblasts from a normal birth and from an IUGR birth are shown in Fig. 1. This pattern of apoptosis was the same in all normal preparations (high at $140 \mathrm{mmHg}$, low at $38 \mathrm{mmHg}$, and higher again at $<10 \mathrm{mmHg}$ (Kilani et al. 2003)). The pattern was 


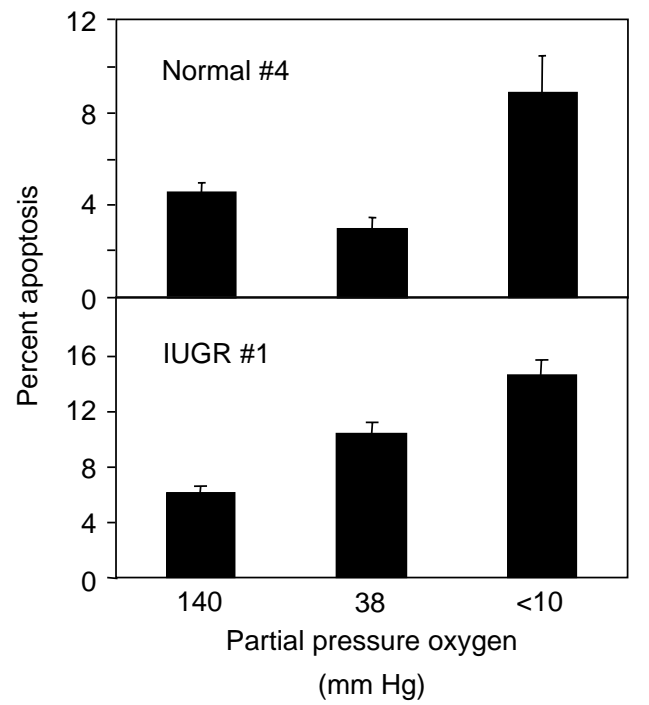

Figure 1 Typical apoptosis frequencies of cytotrophoblasts isolated from placentae from uncomplicated (normal) and IUGR-complicated (IUGR) births. The frequencies measured on a single preparation are shown in the figure (mean \pm s.D. of three wells). Apoptosis and culture procedures are detailed in the Materials and Methods.

different (lowest at $140 \mathrm{mmHg}$, higher at $38 \mathrm{mmHg}$, and slightly higher at $<10 \mathrm{mmHg}$ ) for all IUGR preparations but with considerable scatter in absolute values (data not shown). At $140 \mathrm{mmHg}$, the average apoptosis frequency in CT from normal placentae cultured in 24-well dishes was $6.0 \% \pm 3.8$ and for IUGR was $6.9 \% \pm 3.3$. In order to compare the frequencies for IUGR and normal trophoblast preparations, the apoptosis frequencies of a preparation were normalized to the frequency observed at $140 \mathrm{mmHg}$. The normalized values are shown in Fig. 2

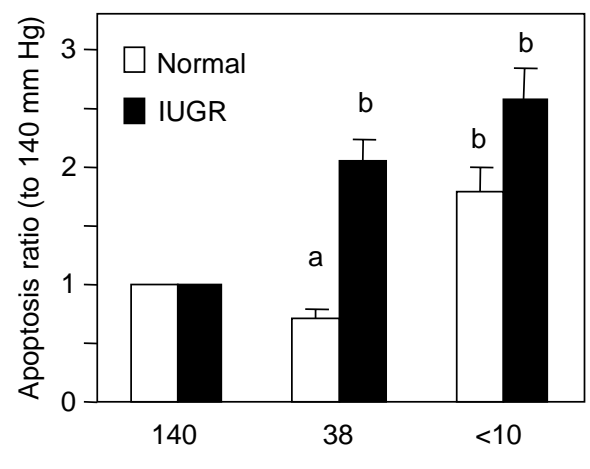

Partial pressure oxygen $(\mathrm{mm} \mathrm{Hg})$

Figure 2 A comparison of the ratio of apoptosis frequencies (at all oxygen levels to the apoptosis at $140 \mathrm{mmHg}$ ) of trophoblasts isolated from placentae of normal (open bars) and IUGR (filled bars)-

complicated pregnancies. The results are pooled data from 20 independent experiments on trophoblast preparations from nine different normal placentae $(n=9)$ and 28 independent experiments on preparations from nine different IUGR placentae $(n=9)$. Depicted are the mean \pm s.D. of the ratios $(140 \mathrm{mmHg} / 140 \mathrm{mmHg}=1)$. Experimental groups labeled with different letters $(\mathrm{a}-\mathrm{b})$ are significantly different $(P<0.05$, two-way ANOVA). with $140 \mathrm{mmHg}$ shown as 1.0. The apoptosis frequencies for normal CT were always lower $(0.71 \pm 0.16)$ at $38 \mathrm{mmHg}$ than at $140 \mathrm{mmHg}$, but the frequencies for IUGR CT were always higher $(2.1 \pm 0.36)$ at $38 \mathrm{mmHg}$ than at $140 \mathrm{mmHg}$. When comparing the values at $38 \mathrm{mmHg}$ by two-way ANOVA analysis, we found that they were statistically different $(P<0.001)$. The apoptosis ratios for both normal and IUGR CT at $<10 \mathrm{mmHg}$ were both high and not different from each other. This comparison showed that the cells from IUGR placentae underwent a much higher ratio of apoptosis at $38 \mathrm{mmHg}$ relative to $140 \mathrm{mmHg}$.

\section{Apoptosis of trophoblasts from normal and IUGR placentae in the absence or presence of antibody to $T N F \alpha$ and absence or presence of added TNF $\alpha$}

TNF $\alpha$ is one of the few cytokines that increases apoptosis in trophoblasts (Yui et al. 1994a, Crocker et al. 2003, Gill \& Hunt 2004). Therefore, we first examined the effect of endogenously produced TNF $\alpha$ on the apoptosis of cells from uncomplicated and IUGR-complicated placentae by calculating the ratio of apoptosis with to without excess TNF $\alpha$ antibody (Fig. 3A). The averages of ratios were near

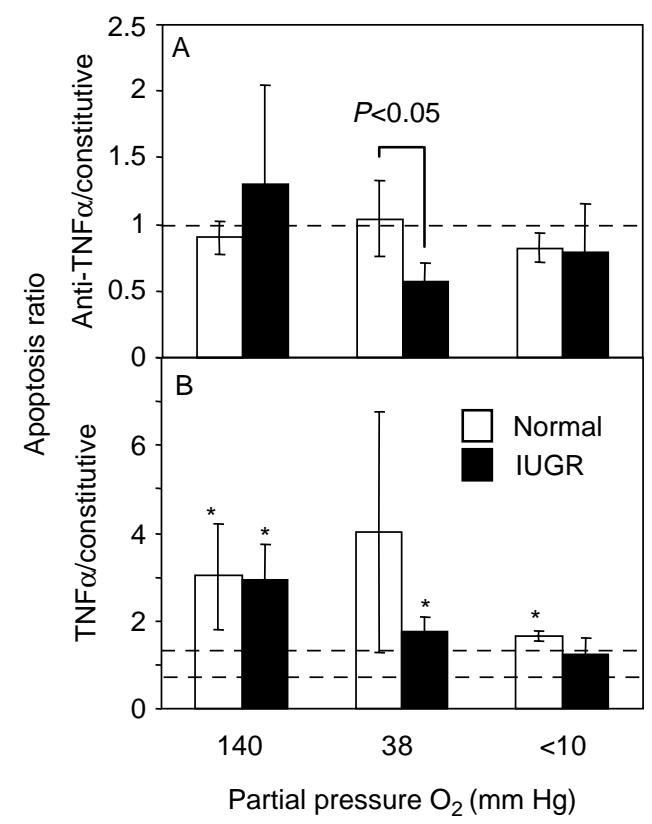

Figure 3 The effect of neutralizing antibody to TNF $\alpha$ and of added TNF $\alpha$ on the apoptosis frequencies of normal and IUGR trophoblasts. (A) Ratio of apoptosis frequencies with to without $2 \mu \mathrm{g} / \mathrm{ml}$ neutralizing antibody to TNF $\alpha$ added to the culture medium. The dashed line is 1.0 (no effect). The ratio of apoptosis of normal and IUGR cells was compared by Student's t-test at $38 \mathrm{mmHg}$. (B) Ratio of apoptosis frequencies with to without $10 \mathrm{ng} / \mathrm{ml} \mathrm{TNF} \alpha$ added to the culture medium. The dashed lines represent the calculated average s.D. of constitutive apoptosis (with at ratio 1.0 being no effect). The levels of apoptosis with to without TNF $\alpha$ were compared in those groups marked with an * by paired Student's $t$-test $(P<0.05$, data not log-transformed prior to carrying out Student's $t$-test). 
unity for both uncomplicated and IUGR CT at $140 \mathrm{mmHg}$ and not significantly different (a ratio of 1.0 is depicted with a dashed line). However, the ratio for IUGR CT was reduced at $38 \mathrm{mmHg}(0.57 \pm 0.15)$ and was significantly $(P<0.05)$ different from the ratio for normal cells $(1.05 \pm$ $0.29)$. At $<10 \mathrm{mmHg}$, there was no significant difference between normal and IUGR. These data show that excess neutralizing antibody to TNF $\alpha$ affected the apoptosis frequency only for IUGR CT at $38 \mathrm{mmHg}$.

We next cultured cells with and without added TNF $\alpha$ (at a near optimal dose of $10 \mathrm{ng} / \mathrm{ml}$; Yui et al. 1994a) and calculated apoptosis ratios with to without TNF $\alpha$. In general, the stimulation of apoptosis by exogenous TNF $\alpha$ decreased with decreasing oxygen tension for both normal and IUGR cells (Fig. 3B). TNF $\alpha$ added to the medium increased apoptosis about threefold at $140 \mathrm{mmHg}$ for both normal and IUGR cells and it barely increased the apoptosis frequencies at $<10 \mathrm{mmHg}$. At $38 \mathrm{mmHg}$, TNF $\alpha$ increased apoptosis of IUGR cells by 1.6-fold and normal cells by greater than fourfold. However, the former increase was statistically significant $(P<0.05)$ but the latter was not, probably because the very low apoptosis of normal cells at $38 \mathrm{mmHg}$ increased the scatter of the ratio (see Fig. 2).

\section{Comparison of TNF $\alpha$ mRNA content of normal and IUGR placentae by qRT-PCR}

The data in Fig. 3 show that endogenous TNF $\alpha$ accounts for a significant fraction (about $45 \%$ ) of spontaneous apoptosis in IUGR cells cultured at an oxygen tension of $38 \mathrm{mmHg}$ (when compared with almost nothing for normal cells). We next examined normal and IUGR cultures for levels of expression of TNF $\alpha$ and the TNF receptor that mediates its apoptotic effects (p55; Yui et al. 1996). Attempts to measure TNF $\alpha$ bioreactivity in the culture supernatants showed that the levels were near the level of detection ( $\sim 1 \mathrm{pg} / \mathrm{ml}$, data not shown). As an alternative method, we quantitatively measured TNF $\alpha$ mRNA levels in the cultures by qRT-PCR. Expression of $18 \mathrm{~S}$ RNA was proportional to the amount of mRNA present (data not shown). The expression of TNF $\alpha$ mRNA relative to 18S RNA was measured in the samples incubated for $3 \mathrm{~h}$ in six-well tissue culture dishes at the three oxygen levels for both IUGR and normal samples (Fig. 4). In normal cells, TNF $\alpha$ mRNA levels slightly decreased with decreasing culture oxygen levels. However, TNF $\alpha$ mRNA levels increased in IUGR cells with decreasing culture oxygen levels. This divergence reached significance at $38 \mathrm{~mm}$ and $<10 \mathrm{mmHg}$ $(P<0.05)$. We next examined the levels of TNF receptor p55 protein (TNF-R1) after $24 \mathrm{~h}$ of culture at the different oxygen levels by western blot analysis (Fig. 5). IUGR cells expressed higher levels of TNF-R1 (relative to $\beta$-actin) at all the three oxygen levels especially after culture at $38 \mathrm{mmHg}$. These data show that the TNF $\alpha$ expression at $38 \mathrm{mmHg}$ was greater in IUGR than

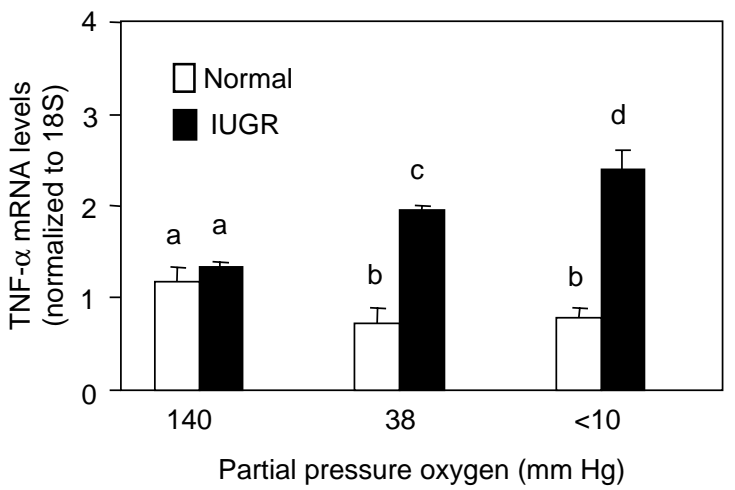

Figure $4 \mathrm{TNF} \alpha$ mRNA levels (normalized to 18S RNA levels) of trophoblasts isolated from normal and IUGR pregnancies after $3 \mathrm{~h}$ of culture. Vertical axis, ratio of TNF $\alpha$ mRNA to $18 \mathrm{~S}$ RNA levels.

Horizontal axis, oxygen level of culture. Open bars, trophoblasts from normal pregnancies. Filled bars, trophoblasts from pregnancies complicated by IUGR. Depicted are the mean \pm s.D. of three samples carried out from different CT purifications. Different letters by the bars (a-d) indicate statistically different groups within each time point (twoway ANOVA analysis, $P<0.05$ ).

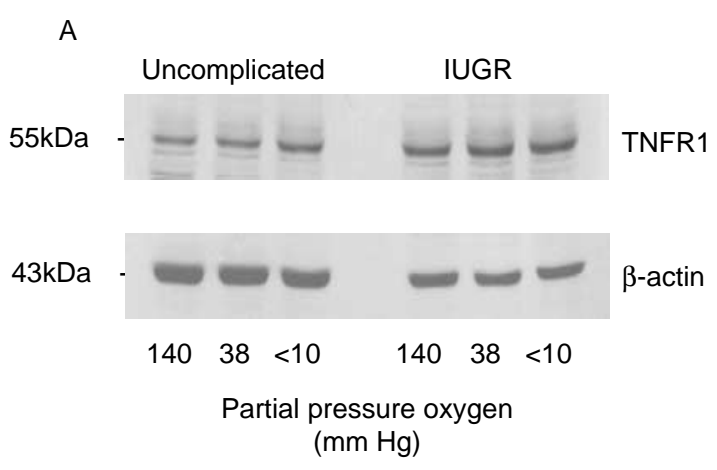

B

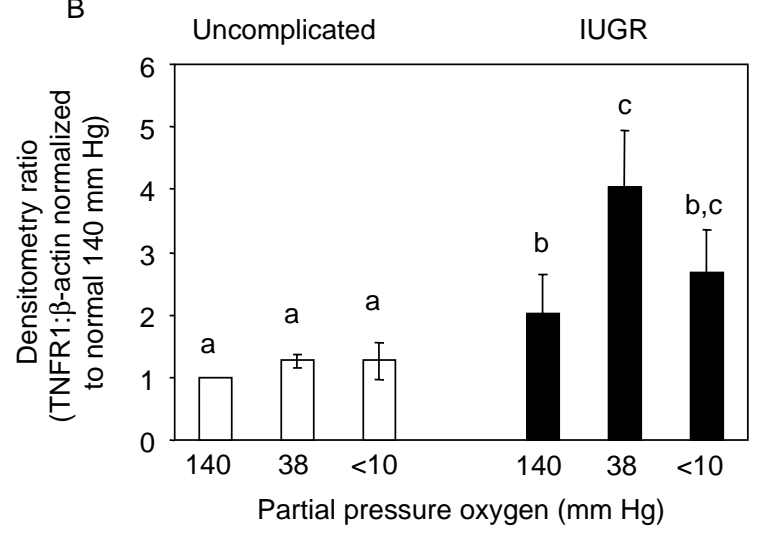

Figure 5 Protein expression of TNF receptor p55 in trophoblasts from uncomplicated and IUGR-complicated pregnancies. (A) A typical western blot analysis of TNFR1 and $\beta$-actin expression in cells from uncomplicated and IUGR-complicated pregnancies after culture at the indicated oxygen levels for $24 \mathrm{~h}$. (B) The blots were scanned for both bands to obtain a ratio of TNFR1 to $\beta$-actin and this ratio was normalized to the $140 \mathrm{mmHg}$ uncomplicated value. Depicted is the mean \pm s.D. of the data from six placentas; three in the IUGR group and three in the normal group. Different letters by the bars $(\mathrm{a}-\mathrm{C})$ indicate statistically different groups within each time point (ANOVA analysis, $P<0.05$ ). 
normal cells and that, in addition, IUGR expressed more receptors.

\section{Discussion}

Based on an earlier study showing that trophoblasts from IUGR placentae had an abnormally high level of apoptosis (Smith et al. 1997) and that CT from normal pregnancies underwent minimal apoptosis at oxygen tensions of 15 and $38 \mathrm{mmHg}$ (Kilani et al. 2003), we hypothesized that the trophoblasts from IUGR-complicated pregnancies would have elevated apoptosis frequencies at the normoxic levels of $38 \mathrm{mmHg}$. For $\mathrm{CT}$ isolated from uncomplicated pregnancies, the ratio of apoptosis at $38-140 \mathrm{mmHg}$ is approximately 0.7 . However, the oxygen dependency for apoptosis of CT from all nine IUGR placentae studied was strikingly different, in that the ratio of apoptosis at $38-140 \mathrm{mmHg}$ was $>2$. Thus, in agreement with our hypothesis, CT isolated from IUGR placentas underwent a greater level of apoptosis at a normoxic (for CT) oxygen level of $38 \mathrm{mmHg}$ than did CT from normal placentas.

The placentas assessed in the present study were segregated into normal and IUGR based on fetal weight at delivery alone: those associated with fetuses in the upper 90th centile of local weight distribution were normal and those with the lower 10th centile were IUGR. Although there was a greater distribution of gestational age at delivery in the IUGR group due in part to a few early onset pre-eclampsia patients, the average ages of delivery were not significantly different. All normal and IUGR placentas were collected and CT isolated in the same manner. No other criterion was used to separate normal from IUGR; thus, the babies were probably small for a variety of reasons. However, in spite of the likely heterogeneity for IUGR baby weights, we still saw significant differences at $38 \mathrm{mmHg}$ oxygen levels for apoptosis, TNF $\alpha$ expression, and expression of the TNF receptor p55 protein.

At the onset of culture (at $5 \mathrm{~h}$ ), most but not all, apoptotic and dying cells were washed away (Guilbert et al. 2002); thus, most of the cells apoptotic at $24 \mathrm{~h}$ became so between 5 and $29 \mathrm{~h}$. Based on our experience with TNF $\alpha$ as an autocrine mediator of cytomegalovirusinduced apoptosis of placental trophoblasts (Chan et al. 2002), we determined whether it was the causative agent. Autocrine production of TNF $\alpha$ was assessed by culturing the cells with excess neutralizing antibody to $\mathrm{TNF} \alpha$. At an oxygen level of $38 \mathrm{mmHg}$, an average of $45 \%$ of the spontaneous apoptosis of IUGR CT was blocked by antibody to TNF $\alpha$ while $<10 \%$ of apoptosis was blocked by antibody in uncomplicated CT (Fig. 2). This $45 \%$ of spontaneous apoptosis for IUGR CT accounts for much of the difference between IUGR and uncomplicated CT.

The large contribution of autocrine TNF $\alpha$ at $38 \mathrm{mmHg}$ was not manifested by measurable supernatant levels of
TNF $\alpha$ protein levels, possibly due to constant uptake by TNF receptors on the cells (both p55 and p75; Yui et al. 1996); thus, we measured TNF $\alpha$ mRNA expression by qRT-PCR. Determination of TNF $\alpha$ mRNA levels by RT-PCR has previously been used for estimating the TNF $\alpha$ expression by human trophoblasts (King et al. 1995, Bennett et al. 1996). Comparing expression of TNF $\alpha$ mRNA on cultured CT at a $\mathrm{pO}_{2}$ of $38 \mathrm{mmHg}$ with that at $140 \mathrm{mmHg}$, we found that cells from an uncomplicated placenta expressed significantly less $(P<0.05$, a $35 \%$ decrease) at $38 \mathrm{mmHg}$ and that IUGR cells expressed more $(P<0.05$, a $55 \%$ increase $)$ at $38 \mathrm{mmHg}$. This divergence (decreasing TNF $\alpha$ expression with decreasing oxygen tension for normal cells and increasing TNF $\alpha$ expression with decreasing oxygen tension for IUGR cells) leads to almost threefold higher levels after culture at $38 \mathrm{mmHg}$ in the IUGR group. One can infer from this finding that IUGR CT produce more biologically active $\mathrm{TNF} \alpha$ than $\mathrm{CT}$ from uncomplicated pregnancies and the cells are responding by undergoing a higher frequency of apoptosis. This inference agrees with the antibody data and supports our hypothesis that there is greater TNF $\alpha$ production in IUGR CT at $38 \mathrm{mmHg}$.

The regulation of TNF $\alpha$ expression as a function of oxygen level appears to be tissue- and disease-specific. Our findings, with highly purified CT, point to a diseasespecific regulation. Hypoxia induced no increase (Hung et al. 2004) or a mild increase (Benyo et al. 1997) in $\mathrm{TNF} \alpha$ secretion from placental explants, which contain other cells (placental macrophages) that express TNF $\alpha$ (Berkowitz et al. 1990). TNF $\alpha$ expression from mouse and human macrophages was either increased with decreasing oxygen tension (VanOtteren et al. 1995) or decreased (Hirani et al. 2001). The regulation of TNF $\alpha$ expression in normal mononuclear phagocytes and CT by hypoxia is complex and not completely understood. However, very clearly, expression of mRNA levels is different in CT isolated from normal and IUGR placentas.

The p55 TNF receptor mediates trophoblast apoptosis (Yui et al. 1996) and we found that the levels of this receptor (measured by western blot analysis) were upregulated in IUGR cells. Levels in normal trophoblasts did not vary as a function of culture oxygen tension but the levels in IUGR cells were consistently higher at all the three oxygen levels and marginally peak at $38 \mathrm{mmHg}$. We are aware that $\beta$-actin mRNA levels fluctuate somewhat with hypoxia (Zhang et al. 2001) and assume that the changes in protein expression will be the same in normal and IUGR cells. These results are in agreement with the observation that oxygen does not regulate the level of TNF-R1 (Hehlgans et al. 2001) and point to a dysregulation in IUGR CT. What the effect of increasing receptor levels in cultured CT is more difficult to predict because of the distribution of cell surface receptor levels among cells (some express none; Yui et al. 1996) and where the receptors are in and on the cell (inside the cell, on the surface, or on the surface but 
destined to be cleaved). However, increasing cellular receptor levels will not have a deleterious effect on response and could well increase it. If p55 receptor level is a measure of capacity to respond to TNF $\alpha$, we have therefore found an enhanced capacity to respond in IUGR cells, especially at $38 \mathrm{mmHg}$ (Fig. 5).

Hypoxia is implicated in the pathogenesis of preterm labor, birth of a small fetus (IUGR), and early miscarriages (Salafia et al. 1995, Pardi et al. 2002, Jauniaux et al. 2006). TNF $\alpha$ upregulation is independently implicated in these pregnancy complications (Gorivodsky et al. 1998, Rivera et al. 1998, Steinborn et al. 1998), although there is controversy concerning miscarriages (Fidel et al. 1997, Lea et al. 1997). The relationship of $\mathrm{TNF} \alpha$ expression to low oxygen, the nature and location of cells expressing TNF $\alpha$, and whether these cells are hypoxic for their location in the placenta remain to be determined. However, we have found that during culture at $38 \mathrm{mmHg}$ (a normoxic oxygen tension for $\mathrm{CT}$ ), apoptosis is increased in $\mathrm{CT}$ from IUGR relative to $C T$ from normal placentae and that this increase in apoptosis is, in part, due to increased TNF $\alpha$. The increase in TNF $\alpha$-induced apoptosis is also linked to an increase in the expression of TNF-R1. The combination could cause an increasing number of CT to undergo apoptosis in IUGR placentae and thereby contribute to placental insufficiency.

\section{Acknowledgements}

We would like to thank the staff of our tissue collection unit at the Royal Alexandra Hospital (Donna Dawson and Walter Sumoski) for their efforts in identifying and collecting IUGR placentae, Dean Zaragoza for statistical analyses, Sheena Fang for assisting with real-time PCR and Bonnie Lowen for technical support. This research was carried out with funds from the Canadian Institutes for Health Research (CIHR, grant no. MOP 69002). Sandra Davidge holds a Canadian Research Chair for Women's Cardiovascular Health and is a Senior Scholar of the AHFMR. The authors declare that there is no conflict of interest that would prejudice the impartiality of this scientific work.

\section{References}

Arenas IA, Xu Y, Lopez-Jaramillo P \& Davidge ST 2004 Angiotensin II-induced MMP-2 release from endothelial cells is mediated by TNF-alpha. American Journal of Physiology. Cell Physiology 286 C779-C784.

Benirschke K \& Kaufmann P 2000 Pathology of the Human Placenta, New York, NY: Springer-Verlag.

Bennett WA, Lagoo-Deenadayalan S, Brackin MN, Hale E \& Cowan BD 1996 Cytokine expression by models of human trophoblast as assessed by a semiquantitative reverse transcription-polymerase chain reaction technique. American Journal of Reproductive Immunology 36 285-294.

Benyo DF, Miles TM \& Conrad KP 1997 Hypoxia stimulates cytokine production by villous explants from the human placenta. Journal of Clinical Endocrinology and Metabolism 82 1582-1588.
Berkowitz RS, Faris HM, Hill JA \& Anderson DJ 1990 Localization of leukocytes and cytokines in chorionic villi of normal placentas and complete hydatidiform moles. Gynecologic Oncology 37 396-400.

Branch DR, Shah A \& Guilbert LJ 1991 A specific and reliable bioassay for the detection of femtomolar levels of human and murine tumor necrosis factors. Journal of Immunological Methods 143 251-261.

Chan G, Hemmings DG, Yurochko AD \& Guilbert LJ 2002 Human cytomegalovirus-caused damage to placental trophoblasts death mediated by immediate-early gene-induced TNF-alpha. American Journal of Pathology 161 1371-1381.

Crocker IP, Cooper S, Ong SC \& Baker PN 2003 Differences in apoptotic susceptibility of cytotrophoblasts and syncytiotrophoblasts in normal pregnancy to those complicated with preeclampsia and intrauterine growth restriction. American Journal of Pathology 162 637-643.

Fidel PLJ, Romero R, Cutright J, Wolf N, Gomez R, Araneda H, Ramirez M \& Yoon BH 1997 Treatment with the interleukin-I receptor antagonist and soluble tumor necrosis factor receptor FC fusion protein does not prevent endotoxin-induced preterm parturition in mice. Jouranal of Society Gynecologic Investigation 4 22-26.

Garcia-Lloret M, Yui J, Winkler-Lowen B \& Guilbert LJ 1996 Epidermal growth factor inhibits cytokine-induced apoptosis of primary human trophoblasts. Journal of Cellular Physiology 167 324-332.

Gavrieli Y, Sherman Y \& Ben-Sasson SA 1992 Identification of programmed cell death in situ via specific labeling of nuclear DNA fragmentation. Journal of Cell Biology 119 493-501.

Gill RM \& Hunt JS 2004 Soluble receptor (DcR3) and cellular inhibitor of apoptosis-2 (clAP-2) protect human cytotrophoblast cells against LIGHT-mediated apoptosis. American Journal of Pathology 165 309-317.

Gorivodsky M, Zemlyak I, Orenstein H, Savion S, Fein A, Torchinsky A \& Toder V 1998 TNF-alpha messenger RNA and protein expression in the uteroplacental unit of mice with pregnancy loss. Journal of Immunology 160 4280-4288.

Guilbert LJ, Winkler-Lowen B, Sherburne R, Rote NS, Li H \& Morrish DW 2002 Preparation and functional characterization of villous cytotrophoblasts free of syncytial fragments. Placenta $\mathbf{2 3}$ 175-183.

Hehlgans T, Seitz C, Lewis C \& Mannel DN 2001 Hypoxic upregulation of TNF receptor type 2 expression involves NF-IL-6 and is independent of HIF-1 or HIF-2. Journal of Interferon \& Cytokine Research 21 757-762.

Hirani N, Antonicelli F, Strieter RM, Wiesener MS, Ratcliffe PJ, Haslett C \& Donnelly SC 2001 The regulation of interleukin-8 by hypoxia in human macrophages - a potential role in the pathogenesis of the acute respiratory distress syndrome (ARDS). Molecular Medicine 7 685-697.

Hung TH, Skepper JN \& Burton GJ 2001 In vitro ischemia-reperfusion injury in term human placenta as a model for oxidative stress in pathological pregnancies. American Journal of Pathology 159 1031-1043.

Hung TH, Charnock-Jones DS, Skepper JN \& Burton GJ 2004 Secretion of tumor necrosis factor-alpha from human placental tissues induced by hypoxia-reoxygenation causes endothelial cell activation in vitro: a potential mediator of the inflammatory response in preeclampsia. American Journal of Pathology 164 1049-1061.

Jauniaux E, Poston L \& Burton GJ 2006 Placental-related diseases of pregnancy: involvement of oxidative stress and implications in human evolution. Human Reproduction Update 12 747-755.

Kilani R, Chang L-J, Hemmings D \& Guilbert LJ 1997 Placental trophoblasts resist infection by multiple HIV-1 variants even with CMV co-infection but support HIV replication after provirus transfection. Journal of Virology 71 6359-6372.

Kilani R, Davidge ST \& Guilbert LJ 2003 The effect of oxygen tension on TNFa/IFNg-induced apoptosis of primary villous cytotrophoblasts. Placenta 24 826-834. 
King A, Jokhi PP, Smith SK, Sharkey AM \& Loke YW 1995 Screening for cytokine mRNA in human villous and extravillous trophoblasts using the reverse-transcriptase polymerase chain reaction (RT-PCR). Cytokine 7 364-371.

Kingdom J, Huppertz B, Seaward G \& Kaufmann P 2000 Development of the placental villous tree and its consequences for fetal growth. European Journal of Obstetrics, Gynecology, and Reproductive Biology 92 35-43.

Laemmli UK 1970 Cleavage of structural proteins during the assembly of the head of bacteriophage T4. Nature 227 680-685.

Lea RG, Tulppala M \& Critchley HOD 1997 Deficient syncytiotrophoblast tumour necrosis factor-alpha characterizes failing first trimester pregnancies in a subgroup of recurrent miscarriage patients. Human Reproduction 12 1313-1320.

Mackova M, Kilani RT, Davidge ST \& Guilbert LJ 2003 The effect of oxygen tension on intracellular signalling in primary villous trophoblasts. Placenta 24 627-637.

Mayhew TM, Ohadike C, Baker PN, Crocker IP, Mitchell C \& Ong SS 2003 Stereological investigation of placental morphology in pregnancies complicated by pre-eclampsia with and without intrauterine growth restriction. Placenta 24 219-226.

Mintz G, Niz J, Gutierrez G, Garcia-Alonso A \& Karchmer S 1986 Prospective study of pregnancy in systemic lupus erythematosus. Results of a multidisciplinary approach. Journal of Rheumatology 13 732-739.

Pardi G, Marconi AM \& Cetin I 2002 Placental-fetal interrelationship in IUGR fetuses - a review. Placenta 23 S136-S141.

Pfaffl MW 2001 A new mathematical model for relative quantification in real-time RT-PCR. Nucleic Acids Research 29 e45.

Rivera DL, Olister SM, Liu X, Thompson JH, Zhang XJ, Pennline K, Azuero R, Clark DA \& Miller MJ 1998 Interleukin-10 attenuates experimental fetal growth restriction and demise. FASEB Journal 12 189-197.

Rubbert A, Pirner K, Wildt L, Kalden JR \& Manger B 1992 Pregnancy course and complications in patients with systemic lupus erythematosus. American Journal of Reproductive Immunology 28 205-207.

Salafia CM, Minior VK, Lopez-Zeno JA, Whittington SS, Pezzullo JC \& Vintzileos AM 1995 Relationship between placental histologic features and umbilical cord blood gases in preterm gestations. American Journal of Obstetrics and Gynecology 173 1058-1064.

Sibley CP, Pardi G, Cetin I, Todros T, Piccoli E, Kaufmann P, Huppertz B, Bulfamante G, Cribiu FM, Ayuk P, Glazier J \& Radaelli T 2002 Pathogenesis of intrauterine growth restriction (IUGR)-conclusions derived from a European union biomed 2 concerted action project. 'Importance of oxygen supply in intrauterine growth restricted pregnancies' - a workshop report. Placenta 23 S75-S79.
Smith SC, Symonds EM \& Baker PN 1997 Increased placental apoptosis in intrauterine growth restriction. American Journal of Obstetrics and Gynecology 177 1395-1401.

Soothill PW, Nicolaides KH, Bilardo K, Hackett GA \& Campbell S 1986 Utero-placental blood velocity resistance index and umbilical venous $\mathrm{pO} 2, \mathrm{pCO} 2, \mathrm{pH}$, lactate and erythroblast count in growthretarded fetuses. Fetal Therapy $\mathbf{1} 176-179$.

Steinborn A, von Gall C, Hildenbrand R, Stutte HJ \& Kaufmann M 1998 Identification of placental cytokine-producing cells in term and preterm labor. Obstetrics and Gynecology 91 329-335.

Ticconi C, Mapfumo M, Dorrucci M, Naha N, Tarira E, Pietropolli A \& Rezza G 2003 Effect of maternal HIV and malaria infection on pregnancy and perinatal outcome in Zimbabwe. Journal of Acquired Immune Deficiency Syndromes 34 289-294.

VanOtteren GM, Standiford TJ, Kunkel SL, Danforth JM \& Strieter RM 1995 Alterations of ambient oxygen tension modulate the expression of tumor necrosis factor and macrophage inflammatory protein-1 alpha from murine alveolar macrophages. American Journal of Respiratory Cell and Molecular Biology 13 399-409.

Wong SF, Chow KM, Leung TN, Ng WF, Ng TK, Shek CC, Ng PC, Lam PW, Ho LC, To WW, Lai ST, Yan WW \& Tan PY 2004 Pregnancy and perinatal outcomes of women with severe acute respiratory syndrome. American Journal of Obstetrics and Gynecology 191 292-297.

Yui J, Garcia-Lloret M, Wegmann TG \& Guilbert LJ 1994a Cytotoxicity of tumour necrosis factor-alpha and gamma-interferon against primary human placental trophoblasts. Placenta 15 819-835.

Yui J, Garcia-Lloret MI, Brown AJ, Berdan DW, Morrish DW, Wegmann TG \& Guilbert LJ 1994b Functional, long-term cultures of human term trophoblasts purified by column-elimination of CD9 expressing cells. Placenta 15 231-246.

Yui J, Hemmings D, Garcia-Lloret M \& Guilbert LJ 1996 Expression of the human p55 and p75 tumor necrosis factor receptors in primary villous trophoblasts and their role in cytotoxic signal transduction. Biology of Reproduction 55 400-409.

Zhang EG, Smith SK, Baker PN \& Charnock-Jones DS 2001 The regulation and localization of angiopoietin-1, -2, and their receptor Tie2 in normal and pathologic human placentae. Molecular Medicine 7 624-635.

Received 26 June 2006

First decision 27 July 2006

Revised manuscript received 20 September 2006

Accepted 27 September 2006 